p-ISSN: 2338-4387

e-ISSN: $2580-3247$

\title{
Analisis Kesulitan Belajar dan Miskonsepsi Mahasiswa dalam Praktikum Berbasis Proyek
}

\author{
Muhammad Nasir \\ Program Studi Tadris (Pendidikan) Fisika, IAIN Palangka Raya \\ e-mail: nasir@iain-palangkaraya.ac.id
}

\begin{abstract}
Abstrak
Tujuan penelitian ini adalah untuk menganalisis kesulitan belajar dan miskonsepsi mahasiswa dalam praktikum berbasis proyek. Pendekatan penelitian menggunakan kualitatif deskriptif. Miskonsepsi mahasiswa diuji menggunakan uji Certainty of Response Index (CRI). Subyek dalam penelitian ini adalah mahasiswa Program Studi Tadris Fisika IAIN Palangka Raya semester dua tahun akademik 2016/2017. Hasil penelitian menunjukkan bahwa 9\% kesulitan belajar mahasiswa dalam menentukan topik, $9 \%$ dalam mengidentifikasi alat dan bahan, $22 \%$ dalam menyusun langkah-langkah percobaan, 35\% dalam menyusun jadwal penyelesaian proyek, 39\% dalam pengambilan data, $4 \%$ dalam menyajikan data, $87 \%$ pada memilih jenis teknik analisis data, $52 \%$ melakukan analisis data, $13 \%$ membahas hasil analisis data, and 4\% mengambil kesimpulan. Miskonsepsi mahasiswa dalam teknik analisis data adalah $74,64 \%$ dan yang tidak paham konsep adalah $3,9 \%$. Kesimpulan penelitian ini adalah kesulitan belajar mahasiswa yang paling tinggi dalam praktikum berbasis proyek adalah pada tahap pemilihan jenis teknik analisis data. Hal ini disebabkan karena mahasiswa mengalami miskonsepsi dan tidak paham konsep teknik analisis data. Saran dari penelitian ini adalah perlunya pemantapan konsep teknik analisis data sebelum diterapkan praktikum berbasis proyek.
\end{abstract}

Kata Kunci: Miskonsepsi Mahasiswa; Kesulitan Belajar; Praktikum Berbasis Proyek;

\begin{abstract}
The aim of this study is to analyze the difficulty of learning and student collage misconception on experiment base project. Research approach used is qualitative descriptive. Student college misconception is tested by Certainty of Response Index (CRI). The subject of this research is physics education student collage of Palangka Raya Islamic state institute. Result of this research show that difficulty of learning student collage are $9 \%$ on determining the topic, $9 \%$ on identification of device and matter, $22 \%$ on arranging the procedure, $35 \%$ on arranging the schedule of project, $39 \%$ on collecting the data, $4 \%$ on displaying the data, $87 \%$ on choosing the data analysis technique, $13 \%$ on discussing the result of data analysis, and $4 \%$ on concluding the result of data analysis. Misconception of student collage on data analysis technique is $74,64 \%$ and not understanding the concept is $3,92 \%$. Result of this research is concluded that the highest of learning difficulty of student collage on choosing the data analysis technique. This case is caused by misconception and not understanding of student collage on data analysis technique. Suggestion of this research is comprehension of student collage on concept of data analysis technique be needed before implementing experiment base project.
\end{abstract}

Keyword: Misconception of student collage; learning difficulty; experiment base project 


\section{PENDAHULUAN}

Pendidikan pada abad ke-21 disadari bahwa bukan hanya dilakukan untuk mengembangkan pengetahuan berdasarkan subyek inti pembelajaran malainkan juga harus diorientasikan agar peserta didik memiliki kemampuan kreatif, kritis, komunikatif sekaligus berkarakter (Abidin, 2014). Salah satu kompetensi utama yang harus dikembangkan dalam konteks pendidikan abad ke-21 adalah keterampilan belajar dan berinovasi (Learning and innovation skills) (Trilling \& Fadel, 2009). Keterampilan belajar dan berinovasi terdiri dari keterampilan berpikir kreatif dan kemampuan pemecahan masalah; kemampuan berkomunikasi dan berkolaborasi; dan kemampuan untuk berkreativitas dan berinovasi. Selain itu juga pada abad ke-21 perlu dikembangkan keterampilan produktif dan akuntabel pada peserta didik agar mampu menunjukkan kemampuannya mengelola proyek tertentu dari tahap perencanaan hingga tahap pengevaluasian dan menunjukkan berbagai atribut yang berhubungan dengan aktivitas produksi yang dilakukan baik dalam hal mengelola waktu, bekerja secara positif dan etis, mampu menyelesaikan banyak tugas, senantiasa berpartisifasi aktif, dan akuntabel atas hasil yang dicapainya.

Tuntutan kompetensi pendidikan yang harus dicapai oleh peserta didik di abad ke-21 sangat tinggi sehingga perlu dikembangkan desain pembelajaran yang relevan untuk mencapai tuntutan kompetensi tersebut. Untuk mendorong kemampuan peserta didik untuk menghasilkan karya kontekstual, baik individual maupun kelompok maka sangat disarankan menggunakan pendekatan pembelajaran yang menghasilkan karya berbasis pemecahan masalah (project based learning). Melalui pembelajaran ini mereka akan lebih kreatif, inovatif, dan lebih produktif, sehingga nantinya mereka akan lebih sukses dalam menghadapi persoalan dan tantangan di zamannya, memasuki masa depan yang lebih baik. Hal ini senada dengan hasil penelitian Lasauskiene and Rauduvaite (2015) berjudul Project Based Learning at University: Teaching Experiences of Lectures menunjukkan the contribution of project based learning to (self) development of learners' general and subject competencies has been widely acknowledged. Pembelajaran berbasis proyek memberikan kontribusi pada pengembangan kompetensi peserta didik secara luas.

Pengertian model pembelajaran berbasis proyek lebih spesifik dikemukakan oleh Helm dan Katz (2001) dalam Abidin (2014), merupakan model pembelajaran yang secara mendalam menggali nilai-nilai dari suatu topik tertentu yang sedang dipelajari. Kata kunci utama model ini adalah adanya kegiatan penelitian yang sengaja dilakukan oleh siswa dengan berfokus pada upaya mencari jawaban atas pertanyaan yang diajukan oleh pendidik. Dalam implementasinya, model ini memberikan peluang yang luas kepada siswa untuk membuat keputusan dalam memilih topik, melakukan penelitian, dan menyelesaikan sebuah proyek tertentu. Model Pembelajaran berbasis proyek adalah model pembelajaran yang secara langsung melibatkan siswa dalam proses pembelajaran melalui kegiatan 
penelitian untuk mengerjakan dan menyelesaikan suatu proyek pembelajaran tertentu. Keunggulan model pembelajaran berbasis proyek dinilai sangat baik dalam mengembangkan berbagai keterampilan dasar yang harus dimiliki siswa termasuk keterampilan berpikir, keterampilan membuat keputusan, kemampuan berkreativitas, kemampuan memecahkan masalah, dan sekaligus efektif untuk mengembangkan rasa percaya diri dan manajemen diri para siswa (Abidin, 2014).

Model pembelajaran berbasis proyek dipilih untuk dikembangkan dalam pembelajaran mata kuliah alat ukur dasar fisika karena model ini mampu memberikan latihan peserta didik bagaimana cara belajar (lerning how to learn). Menanamkan bagaimana cara belajar pada peserta didik sangat perlu dilakukan oleh pendidik untuk membekali peserta didik agar bisa belajar sepanjang hayat. Pentingnya penanaman bagaimana cara belajar ini sebagaimana dinyatakan oleh Raka Joni dalam Jepri (2010) bahwa pendidik dituntut untuk mampu merancang pembelajaran yang memiliki karakteristik sebagai berikut (1) melakukan proses pembelajaran bagaimana belajar (lerning how to learn); (2) mengutamakan strategi yang mendukung proses belajar yang bermakna; (3) membantu peserta didik agar cakap dalam memikirkan dan memilih jawaban atas persoalan yang dihadapkan kepadanya; dan (4) pendidik tidak banyak menyampaikan informasi langsung kepada peserta didik. Selian itu juga model pembelajaran berbasis proyek dapat memberikan latihan peserta didik untuk belajar dengan melakukan (learnig to do).

Learning to do mengandung makna bahwa belajar bukanlah sekedar mendengar dan melihat untuk mengakumulasi pengetahuan, akan tetapi belajar dengan dan untuk melakukan suatu aktivitas dengan tujuan akhir untuk menguasai kompetensi yang diperlukan dalam menghadapi tantangan kehidupan. Kompetensi akan dapat dimilki oleh peserta didik apabila diberikan kesempatan untuk belajar dengan melakukan apa yang harus dipelajari secara langsung. Berkaitan dengan pengembangan desain pembelajaran harus berorientasi untuk melatih peserta didik untuk bagaimana belajar (lerning how to learn) dan belajar dengan melakukan (learnig to do) maka peneliti tertarik untuk menerapkan model pembelajaran berbasis proyek dalam bentuk praktikum berbasis proyek.

Praktikum berbasis proyek dapat dilaksanakan menggunakan penuntun praktikumnya yang berbasis proyek. Hasil penelitian (Pasaribu, 2016) menunjukkan bahwa penuntun praktikum inovatif berbasis proyek dan inkuiri lebih efektif diterapkan dalam pembelajaran dibandingkan dengan petunjuk praktikum verifikasi yang ada disekolah. Lebih lanjut hasil penelitian Emalfida (2016) menunjukkan bahwa Lembar Kerja Peserta Didik (LKPD) berbasis Project Based Learning (PJBL) dapat meningkatkan sikap ilmiah peserta didik.

Model pembelajaran praktikum berbasis proyek perlu dikembangkan di Program Studi Tadris Fisika karena sebelumnya pada praktikum fisika dasar I dan fisika dasar II dilakukan secara terstruktur. Mahasiswa praktikum dibimbing oleh assiten yang dipandu oleh petunjuk 
praktikum bersifat verifikatif. Praktikum verifikatif tidak menuntut kreativitas dan kemandirian mahasiswa dalam merencanakan dan melaksanakan kegiatan praktikum melainkan peserta didik hanya diarahkan untuk melakukan aktivitas sesuai dengan langkah-langkah percobaan melalui bimbingan assisten. Dengan demikian, pengembangan desain model pembelajaran berbasis proyek di program studi Tadris Fisika IAIN Palangka Raya perlu dikembangkan untuk memberikan pengalaman pada mahasiswa lebih kreatif dan mandiri menentukan topik prkatikum, merencanakan, melaksanakan, dan mengevaluasi hasilnnya. Pendidik hanya sebagai pengarah dan memonitoring pelaksanaan praktikum berbasis proyek.

Penerapan praktikum berbasis proyek dalam pembelajaran perlu dianalisis kesulitan belajar peserta didik pada setiap tahapan model pembelajaran tersebut. Melalui analisis kesulitan belajar ini dapat ditemukan kesulitan belajar yang dominan pada setiap tahapan (sintax) pembelajaran. selain itu juga, perlu ditilik lebih dalam penyebab utama dominansi kesulitan belajar peserta didik sebagai bahan untuk melakukan perbaikan proses pembelajaran. Proses perbaikan dalam penerapan atau pengembangan suatu model pembelajaran sangat diperlukan oleh pendidik sebagai bahan perbaikan yang berkelanjutan.

Dick, Carey, dan Carey (2009) menyatakan bahwa pengembangan desain pembelajaran merupakan seperangkat kegiatan yang meliputi perencanaan, pengembangan, dan evaluasi terhadap sistem instruksional yang sedang dikembangkan sehingga setelah mengalami beberapa kali revisi, desain system pembelajaran tersebut dapat memuaskan hati pengembangnya. Tahapan yang harus dilalui dalam pengembangan desain pembelajaran adalah 10 tahapan, salah satunya adalah analisis kebutuhan untuk menentukan tujuan pembelajaran (Asses needs to identify goals).

Analisis kebutuhan untuk menentukan tujuan pembelajaran. secara garis besar untuk mendapatkan informasi tentang tujuan yang diharapkan dapat dilakukan melalui analisis awal dan akhir (front-end analysis) yang teridiri dari analisis performa, analisis kebutuhan, analisis pekerjaan, pengalaman praktis tentang kesulitan siswa belajar, dan beberapa konsep baru yang dibutuhkan dalam pembelajaran. analisis kesulitan siswa belajar dan konsep baru yang dibutuhkan dilakukan agar pembelajaran dapat dikembangkan untuk meminimalisasi kesulitan dan kegagalan peserta didik sekaligus membekali peserta didik dengan hal-hal baru yang dapat mempermudah proses pembelajaran. mengingat pentingnya analisis kesulitan belajar dan analisis pemahaman konsep peserta didik sebagai acuan penyusunan tujuan pembelajaran dan perbaikan proses pembelajaran maka penelitian ini dilakukan dengan tujuan untuk menganalisis kesulitan belajar dan miskonsepsi mahasiswa dalam praktikum berbasis proyek pada mata kuliah alat ukur dasar fisika. Analisis ini sangat penting dilakukan sebagai bahan konstruktif untuk perbaikan desaian model praktikum berbasis poyek pada tahun akademik berikutnya. 


\section{METODE}

Pendekatan penelitian ini menggunakan pendekatan penelitian kualitatif deskriptif. Melalui pendekatan deskriftif kualitatif ini dapat dideskripsikan jenis-jenis kesulitan mahasiswa dalam melakukan kegiatan praktikum berbasis proyek pada mata kuliah alat ukur dasar fisika. Metode analisis data yang digunakan dalam penelitian ini adalah metode analisis data kualitatif yang dilakukan melalui tiga tahap (Siswono, 2008) yaitu: (1) Reduksi data, yaitu proses penyederhanaan yang dilakukan melalui seleksi, pemfokusan, dan pengabstraksian data mentah menjadi data bermakna. (2) Paparan data, yaitu proses penampilan data secara lebih sederhana dalam bentuk naratif, refresentasi tabular termasuk dalam bentuk matriks dan grafis. (3) Penyimpulan, yaitu proses pengambilan intisari dari sajian data yang telah terorganisasi dalam bentuk kalimat atau formula yang singkat dan padat tetapi mengandung pengertian luas. Miskonsepsi mahasiswa diuji menggunkan Certainty of Response Index (CRI). Skala CRI yang digunakan dapat dilihat pada Tabel 1.

Tabel 1. Skala Certainty of Response Index (CRI)

\begin{tabular}{cl}
\hline Skala & \multicolumn{1}{c}{ Kategori } \\
\hline 0 & Benar-benar Tidak Tahu \\
1 & Agak Tahu \\
2 & Tidak Yakin \\
3 & Yakin \\
4 & Agak Yakin \\
5 & Sangat Yakin \\
\hline
\end{tabular}

Analisis miskonsepsi menggunkanan CRI dapat menklasifikasikan tingkat pemahaman mahasiswa menjadi tiga kategori yaitu paham konsep, tidak paham konsep dan miskonsepsi, seperti terlihat pada Tabel 2.

Tabel 2. Klasifikasi kategori pemahaman berdasarkan skor CRI

\begin{tabular}{cll}
\hline Jawaban & CRI Rendah $(<2,5)$ & \multicolumn{1}{c}{ CRI Tinggi $(>2,5)$} \\
\hline Benar & Hanya menebak (tidak paham konsep) & Paham Konsep \\
Salah & Tidak paham Konsep & Miskonsepsi \\
\hline
\end{tabular}

Subyek dalam penelitian ini adalah mahasiswa semester dua Program Studi Tadris Fisika IAIN Palangka Raya tahun akademik 2016/2017. Teknik pengambilan sampel dilakukan dengan teknik purpose sampling. Instrumen penggalian data menggunakan teknik observasi presentasi kemajuan proyek mahasiswa. Teknik keabsahan data penelitian menggunakan teknik triangulasi data dalam bentuk menggandakan metode pengukuran yaitu menggunakan metode observasi, angket, dan wawancara terstruktur.

\section{HASIL DAN PEMBAHASAN}

Praktikum berbasis proyek yang telah dilaksanakan dalam mata kuliah alat ukur dasar fisika terdiri dari enam topik yaitu (1) Pengukuran Tegangan AC Menggunkan Osiloskop, (2) 60 | Edu Sains: Jurnal Pendidikan Sains \& Matematika, Vol.5 No.1; 2017 
Viskositas Zat Cair dengan Hukum Stokes, (3) Pengukuran Kapasitas Kalor (4) Menentukan Panjang Fokus Lensa Cembung, (5) Mikrometer Sekrup dan Jangka Sorong, (6) Resistor dan Hukum Ohm. Indikator yang dianalisis antara lain kesulitan dalam menentukan topik, kesulitan dalam mengidentifikasi alat dan bahan, kesulitan dalam menyusun langkahlangkah percobaan, kesulitan dalam menyusun jadwal penyelesaian proyek, kesulitan dalam pengambilan data, kesulitan dalam menyajikan data dalam bentuk tabel hasil pengamatan, kesulitan dalam memilih jenis teknik analisis data, kesulitan dalam melakukan analisis data, kesulitan dalam membahas hasil analisis data, dan kesulitan dalam mengambil kesimpulan.

Hasil observasi presentasi penyajian produk proyek didapatkan empat kelompok (70\%) yang menggunakan teknik analisis data yang tidak sesuai dengan tujuan praktikum dan karakteristik data yang didapatkan. Berdasarkan phenomena ini, peneliti memfokuskan diri untuk menganalisis kesulitan mahasiswa dalam pembelajaran praktikum berbasisi proyek dengan cara menyebarkan angket diagnosis kesulitan belajar mahasiswa. Rekapitulasi prosentase kesulitan belajar mahasiswa disetiap tahapan praktikum berbasis proyek didapatkan seperti pada tabel 3.

Tabel 3. Rekapitulasi Prosentase Kesulitan Belajar Mahasiswa

\begin{tabular}{llc}
\hline No & Aspek yang Dianalisis & Jumlah \\
\hline 1. & kesulitan dalam menentukan topik & $9 \%$ \\
2. & kesulitan dalam mengidentifikasi alat dan bahan & $9 \%$ \\
3. & kesulitan dalam menyusun langkah-langkah percobaan & $22 \%$ \\
4. & kesulitan dalam menyusun jadwal penyelesaian proyek & $35 \%$ \\
5. & kesulitan dalam pengambilan data & $39 \%$ \\
6. & kesulitan dalam menyajikan data dalam bentuk tabel hasil & $4 \%$ \\
7. & kesulitan dalam memilih jenis teknik analisis data & $87 \%$ \\
8. & kesulitan dalam melakukan analisis data & $52 \%$ \\
9. & kesulitan dalam membahas hasil analisis data & $13 \%$ \\
10. & kesulitan dalam mengambil kesimpulan & $4 \%$ \\
\hline
\end{tabular}

Prosentase kesulitan belajar mahasiswa tertinggi adalah $87 \%$ pada tahap memilih jenis teknik analisis data yang sesuai dengan tujuan percobaan dan karakteristik data hasil percobaan. Hasil analisis yang didapatkan konsisten dengan hasil observasi bahwa mahasiswa mengalami kesulitan dalam hal memilih jenis teknik analisis data yang relevan. Untuk menganalisis lebih dalam kesulitan mahasiswa dalam menentukan jenis teknik analisis data yang tepat dilakukan uji Certainty of Response Index (CRI) terhadap miskonsepsi teknik analisis data yang digunakan. Uji miskonsepsi ini bertujuan untuk mengetahui tingkat pemahaman mahasiswa. Senada dengan hasil penelitian hafizah (2014) tentang analisis miskonsepsi yang bertujuan untuk mengetahui kelemahan peserta didik 61 | Edu Sains: Jurnal Pendidikan Sains \& Matematika, Vol.5 No.1; 2017 
dalam menguasai konsep fisika sehingga pendidik perlu mengadakan remediasi bagi peserta didik yang mengalami miskonsepsi untuk menghindari miskonsepsi yang berkelanjutan.

Sub bab teknik analisis data yang dianalisis antara lain (1) metode nilai skala terkecil (NST), (2) metode simpangan baku, (3) metode perambatan ralat, (4) metode kuadrat terkecil, dan (5) metode grafik. Dari 20 mahasiswa yang mengalami kesulitan terhadap teknik analisis data didapatkan $74,64 \%$ yang mengalami miskonsepsi, 3, 92\% yang tidak paham konsep teknik analisis data, dan 21,42\% yang mengalami konsepsi. Deskripsi pemahaman konsep teknik analisis data mahasiswa pada setiap indikator dapat dilihat pada Grafik 1 berikut.

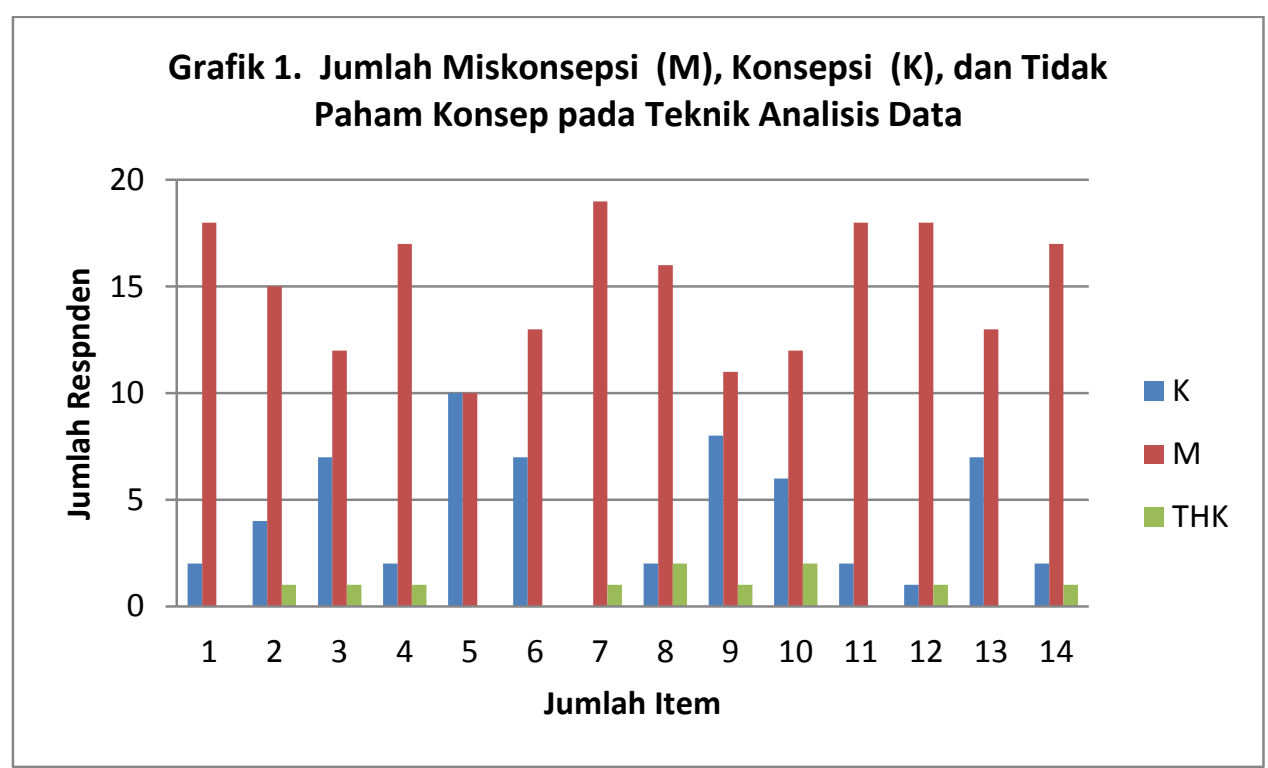

Hasil analisis angket tentang respon mahasiswa terhadap keyakinan terhadap ketepatan teknik analisis data yang dipilih dalam praktikum berbasis proyek dapat dilihat pada Diagram 1 berikut.

Digram 1. Tingkat Keyakinan Mahasiswa Terhadap Ketepatan Teknik Analisis Data yang Digunakan

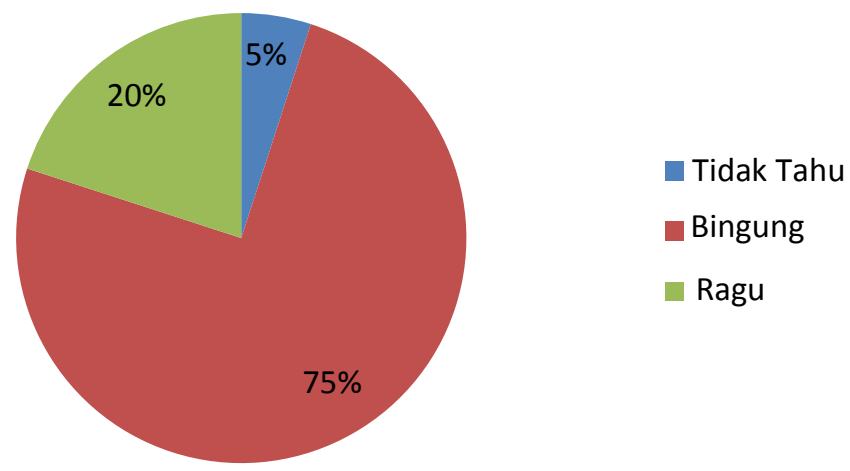


Hasil analisis wawancara terstruktur untuk menemukan trend alasan kenapa mahasiswa mengalami kesulitan dalam menentukan teknik analisis data yang tepat dalam praktikum berbasis proyek terlihat pada Tabel 4 berikut.

Tabel 4. Trend Alasan Kesulitan Belajar Mahasiswa

\begin{tabular}{lll}
\hline No & \multicolumn{1}{c}{ Trend Alasan } & Jumlah \\
\hline 1. & Masih bingung dalam memilih jenis teknik analisis data & $69 \%$ \\
2. & Masih ragu atau sulit membedakan jenis analisis data & $19 \%$ \\
3. & Masih ada jenis teknik analisis data yang belum pernah diterapkan & $12 \%$ \\
& pada saat prraktikum sebelumnya (prkatikum Fisdas I dan II) &
\end{tabular}

Kesulitan belajar mahasiswa tadris fisika semester dua tahun akademik 2016/2017 dalam praktikum berbasis proyek pada mata kuliah alat ukur dasar fisika terdapat pada tahap pemilihan jenis teknik analisis data yaitu sebesar $87 \%$ walaupun sudah dijelaskan jenis-jenis teknik analisis data sebelum pelaksanaan praktikum berbasis proyek. Setelah ditilik lebih dalam pemahaman konsep mahasiswa terhadap teknik analisis data yang sudah dijelaskan ternyata didapatkan masih banyak mahasiswa yang mengalami miskonsepsi pada teknik analisis data sebanyak $74,64 \%$ dan yang tidak paham konsep teknik analisis data sebanyak $3,92 \%$. Kesalahan pada tahap analisis data ini dapat menyebabkan kesalahan dalam mengolah hasil percobaan yang berimplikasi terhadap kesalahan dalam menginterpretasi dan menyimpulkan hasil percobaan. Oleh karena itu perlu dianalisis trend penyebab kesulitan dan lemahnya konsep mahasiswa tentang teknik analisis data.

Trend pertama, mahasiswa masih bingung dalam memilih jenis teknik analisis data yang tepat disebabkan oleh kurangnya pemahaman mahasiswa terhadap teknik analisis data hasil percobaan. Pemahaman mahasiswa terhadap analisis data masih hanya sampai mengenal jenis teknik analisis data dan rumusnya saja namun belum mampu mengidentifikasi ketepatan teknik analisis data dengan jenis pengukuran dan karakteristik data yang dikumpulkan.

Trend kedua, Mahasiswa masih ragu dalam menentukan teknik analisis data yang tepat disebabkan karena pemahaman mahasiswa terhadap teknik analisis data belum komprehensip. Ada sebagian konsep yang sudah dipahami dan sebagian konsep belum dipahami.

Trend ketiga, Masih ada jenis teknik analisis data yang belum pernah diterapkan pada saat prraktikum sebelumnya (prkatikum Fisdas I dan II) disebabkan karena belum terbiasa menggunakan berbagai jenis teknik analisis data dalam praktikum sebelumnya. Teknik analisis data yang biasa digunakan dalam praktikum fisika dasar I dan II adalah metode setengah sekala terkecil dan metode simpangan baku sedangkan metode perambatan ralat, 
metode kuadrat terkecil, dan metode garis sejajar belum diperkenalkan. Selain itu juga, mahasiswa praktikum menggunakan petunjuk praktikum verifikasi sehingga tidak ada kemadirian mahasiswa dalam menentukan teknik analisis data melainkan mengikuti teknik analisis data yang sudah ada pada petunjuk praktikum. Kelebihan praktikum berbasis proyek dibandingkan dengan praktikum verifikasi adalah pada praktikum berbasis proyek terdapat tahap penyajian karya atau produk yang dapat dilakukan melalui presentasi produk. Kegiatan ini dapat melatih kemandirian mahasiswa dan evaluasi pengalaman proyek. Untuk mengasah dan meningkatkan kemampuan penyajian atau presentasi produk proyek dapat dilakukan dengan cara membiasakan diri berani berbicara di depan umum dan banyak menggali ilmu atau informasi yang relevan dengan proyek yang dilakukan (Sani,2015), harapannya agar mampu mentransfer pengalaman yang lebih bermakna kepada peserta didik yang lainnya.

\section{SIMPULAN}

Simpulan penelitian ini adalah kesulitan belajar mahasiswa yang paling tinggi dalam praktikum berbasis proyek adalah pada tahap pemilihan jenis teknik analisis data, yakni sebesar $87 \%$. Hal ini disebabkan karena mahasiswa mengalami miskonsepsi dan tidak paham konsep teknik analisis data. Saran dari penelitian ini adalah perlunya pemantapan konsep teknik analisis data sebelum diterapkan praktikum berbasis proyek.

\section{DAFTAR PUSTAKA}

Abidin,Y.2014. Desain sistem pembelajaran dalam konteks kurikulum 2013. Bandung: PT Refika Aditama.

Dick, W., Care, L., Carey, J.O. 2009. The systemic design of instruction. New jersey: Pearson.

Emalfida, Sarong,M.A \& Hasanuddin. 2016. Pemanfaatan lembar kerja peserta didik (LKDP) berbasis project based learning (PJBL) terhadap peningkatan sikap ilmiah peserta didik MTs Al- Furqan bambi. Jurnal EduBio Tropika, Volume 4(1): 24-28.

Jupri, A.W. 2010. Belajar dan pembelajaran sains. Mataram: Arga Puji Press.

Siswono. 2008. Mengajar dan meneliti. Surabaya: Unesa University Press.

Pasaribu, B.S. 2016. Analisis dan pengembangan penuntun praktikum inovatif yang terintegrasi berbasis proyek dan inkuiri untuk SMA kelas XI semester I materi hidrokarbon sesuia kurikulum 2013. Tesis. Program Pascasarjana Universitas Negeri Medan.

Sani, R.A, Jubaedah,Y \& Ana. 2015. Analisis kemampuan mahasiswa dalam penyajian produk workshop MSDK berbasis project based learning. Jurnal Family Edu, 1(1): 2539. 
Hafizah, D, Haris,V \& Eliwatis. 2014. analisis miskonsepsi siswa melalui tes multiple choice menggunakan certainty of response index pada mata pelajaran fisika man 1 bukittinggi. Edusainstika Jurnal Pendidikan MIPA, 100-103.

Lasaukiene, J.\& Rauduvaite, A. 2015 project based learning at University:Teaching Experiences of Lectures. Prosedia Social and Behavioral Sciences), 788-792.

Trilling, B. \& Fadel, C. 2009 21st century skills: learning for life in our time. San Francisco: Jossey-Bass A Wiley Imprint. 